\title{
Localization of thyrotropin-releasing hormone receptor and thyrotroph embryonic factor on mouse Chromosome 15
}

\author{
Amy C. Lossie, ${ }^{1}$ David F. Gordon, ${ }^{2}$ Sally A. Camper ${ }^{1}$ \\ ${ }^{1}$ Department of Human Genetics, The University of Michigan Medical School, Ann Arbor, Michigan 48109-0618, USA \\ ${ }^{2}$ Department of Medicine, University of Colorado Health Science Center, Denver, Colorado 80262, USA \\ Received: 11 June 1993 / Accepted: 1 July 1993
}

We report the localization of two genes expressed in anterior pituitary thyrotrope cells, thyrotropinreleasing hormone receptor (Trhr) and thyrotroph embryonic factor (Tef), on mouse Chr 15. Trhr is a G-protein-coupled receptor that activates the inositol phospholipid-calcium-protein kinase $\mathrm{C}$ transduction pathway upon the binding of the hypothalamic factor, thyrotropin-releasing hormone (TRH; Straub et al. 1990). TRH increases the production and secretion of thyroid stimulating hormone (TSH) by anterior pituitary thyrotrope cells. TSH is necessary for growth because of its role in the development of the thyroid gland and the production of thyroid hormone. Tef is a leucine zipper transcription factor that is related to the bZIP family (Drolet et al. 1991). While Tef is expressed broadly in the adult, expression in the embryo is confined to the developing thyrotrope cells of the anterior pituitary (Drolet et al. 1991). This expression follows the same temporal and spatial pattern of the beta subunit of TSH (Tshb). Moreover, Tef has been shown to bind three sites in the mouse $T S H b$ promoter and stimulate $T s h b$ promoter activity in transiently transfected CV-1 cells (Drolet et al. 1991).

Using an interspecific backcross provided by The Jackson Laboratory, $(\mathrm{C} 57 \mathrm{BL} / 6 \mathrm{~J} \times M$. spretus $) \mathrm{F}_{1} \times M$. spretus, we localized Trhr and Tef on mouse Chr 15. We first linked Trhr and Tef to mouse Chr 15 by haplotype analysis with two simple sequence repeat markers that were previously characterized on this cross, D15Mit3 and D15Mit16 (The Jackson Laboratory, unpublished results). We then confirmed the localization of Trhr and Tef with D15Mit10.

Trhr and Tef were typed with RFLPs that were detected by Southern blot analysis, performed as previously described (Lossie et al. 1993). A 980-bp $E c o$ RV to BstXII fragment, which corresponds to amino acids 371 to 393 plus $900 \mathrm{bp}$ of $3^{\prime}$ untranslated

Correspondence to: S.A. Camper region, was isolated from the mouse $T r h r$ cDNA clone, pBSm TRHR (Straub et al. 1990), labeled by the random hexanucleotide method (Feinberg and Vogelstein 1982), and hybridized at $65^{\circ} \mathrm{C}$ to blots prepared from genomic DNA digested with TaqI. This detected a C57BL/6J specific allele of $14.2 \mathrm{~kb}$ and an $M$. spretus specific allele of $6.3 \mathrm{~kb}$. Southern blots of genomic DNA digested with $B g l I I$ were hybridized at $57^{\circ} \mathrm{C}$ to an 800-bp Tef cDNA clone. The Tef cDNA fragment was prepared by reverse transcription of mRNA from mouse thyrotropic tumor cells and subsequent PCR amplification with oligonucleotide primers. The primers were designed from the rat sequence to span the start and stop codons, thus amplifying the open reading frame (Drolet et al. 1991). The 30 mer oligonucleotide primer 5'-GCGGATCCATGGAGAACCCCCCGCGCGAGA-3' spans the starting ATG and introduces a $\mathrm{BamHI}$ site. The 36 mer oligonucleotide primer 5'-GCGAATTCTTACAAGGGCCCGTACTTGGTCTCATAC-3' spans the termination codon and adds an EcoRI site. The resulting amplification product was purified and cloned into pGEM11 (Promega). The identity of the clone was verified by DNA sequencing. Tef cDNA hybridized to fragments of 6.1 , 5.5 , and $3.5 \mathrm{~kb}$ in C57BL/6J DNA and to fragments of $7.2,5.5$, and $3.2 \mathrm{~kb}$ in $M$. spretus DNA.

D15Mit10 was mapped by PCR with $100 \mathrm{ng}$ of mouse genomic DNA in a $10-\mu l$ reaction as previously described (Lossie et al. 1993). The resulting polymorphic amplification products were separated on a $2 \%$ agarose gel and yielded bands of $230 \mathrm{bp}$ for the C57BL/ 6J DNA and $170 \mathrm{bp}$ for the $M$. spretus DNA.

We established the unambiguous gene order on the basis of haplotype analysis of 86 backcross progeny (Fig. 1). The intergenic distances (cM) were determined, and standard error was calculated with these and additional animals: D15Mit10-10.1 $\pm 3.2-T r h r-$ $13.2 \pm 3.6-D 15$ Mit3-8.6 \pm 2.9-Tef-11.0 $\pm 3.3-$ D15Mit16 (Fig. 2). The relative positions of the anchor loci, $M y c$ and $G d c-1$, were estimated from data previ- 


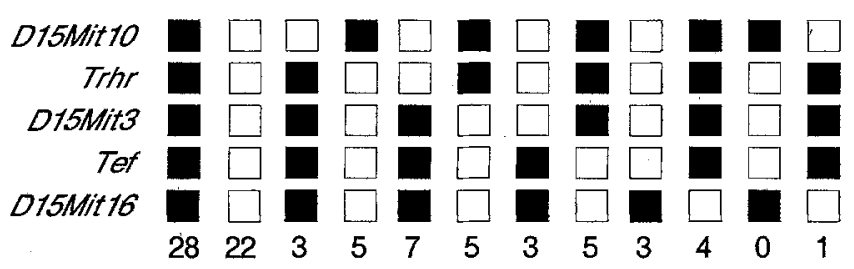

Fig. 1. Haplotype distribution of 86 backcross progeny. Each column represents a chromosomal haplotype. The number of animals observed with each haplotype is given below the column. Animals were scored at each locus (left) as heterozygous for the $M$. spretus and C57BL/6J alleles ( $\mathbf{H}$ ) or homozygous for the $M$. spretus alleles (口).

ously reported (Brannan et al. 1992; Dietrich et al. 1992; Domalik et al. 1991; Eicher and Lee 1991). The ordering of the simple sequence repeat markers is consistent with the previous report (Dietrich et al. 1992). The genetic distances between loci on proximal and distal Chr 15 are known to vary significantly between crosses (Brannan et al. 1992; Dietrich et al. 1992; Domalik et al. 1991; Eicher and Lee 1991; Mock et al. 1991). Variability between crosses is not uncommon (Reeves et al., 1990).

Genes from human Chr 5, 8, 11, 22, and 12 have been assigned to mouse Chr 15 (Mock et al. 1991). Our localization of $T r h r$ places it close to two genes that have been mapped to human chromosome 8q, Myc and Tgn. The assignment of TRHR to the long arm of human Chr 8 (Eidne et al. 1993) is consistent with our localization and extends the previously observed synteny conservation between human Chr 8 and mouse Chr 15.

Both Trhr and Tef are expressed in nonpituitary tissues in adults (Drolet et al. 1991; Straub et al. 1990), suggesting that lesions in these genes could produce pleotropic effects or lethality. However, the expression and expected role of these genes in thyrotrope function suggest that lesions in Trhr or Tef would directly affect the function of the thyroid gland, leading

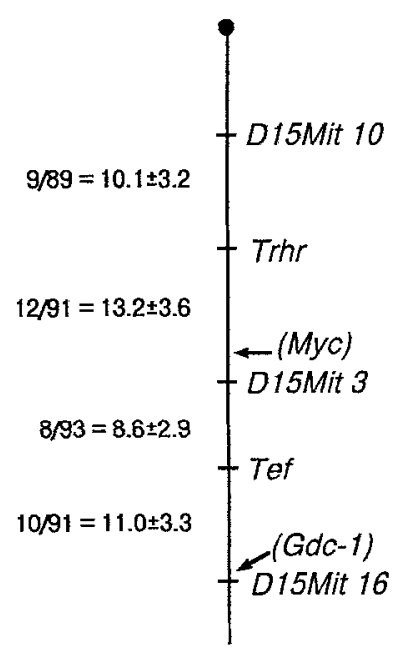

Fig. 2. Genetic map of Chr 15. This linkage map of mouse Chr 15 was constructed on the basis of the haplotype analysis of loci reported here. The map distances, in cM, were calculated from the recombinant fraction observed for each interval (left). The approximate positions of the anchor loci $M y c$ and $G d c-l$ are indicated. to hyper- or hypothyroidism. In such a case, we would expect animals to be normal sized at birth but exhibit a subsequent increase or decrease in growth. Two mouse mutations on Chr 15 are characterized by small size, miniature $(m n)$ and congenital goiter ( $\operatorname{cog}$; Lyon and Searle 1989). Evaluation of the endocrinology of $\operatorname{cog} / \operatorname{cog}$ mice suggested that the synthesis or processing of thyroglobulin (Tgn) is defective, resulting in primary hypoythyroidism (Beamer et al. 1987). This hypothesis is strongly supported by the demonstration that Tgn and $\operatorname{cog}$ cosegregate (Taylor and Rowe 1987), although the molecular basis for the defect has not been described. Mice homozygous for $m n$ are $25 \%$ smaller than their normal littermates at birth, but have normal body proportions (Bennett 1961). They exhibit a dorsal-ventral flattening of the skull and unusually high rates of mortality, especially in early development (Bennett 1961). The $m n$ mutation has been linked to $C a, N$, and $b t$ on Chr 15 , but the lethality of $m n / m n$ mice complicated the determination of gene order (Wallace and Mallyon 1972). Thus, further mapping studies are necessary to determine the localization of $m n$ in relation to $T e f$ and $T r h r$.

Acknowledgments. We would like to especially thank Dean Turner for providing the localization information on D15Mit3 and D15Mit16; the staff of The Jackson Laboratory for providing us with the DNA from the $\left(\mathrm{C} 57 \mathrm{BL} / 6 \mathrm{~J} \times M\right.$. spretus) $\mathrm{F}_{1} \times M$. spretus backcross panel; and Marvin Gershengorn, Cornell University, for providing the Trhr cDNA. We thank Marion S. Buckwalter for contributions to the early stages of this work, Joe Nadeau for encouragement, and the University of Michigan Reproductive Science Center Molecular Biology core (NIH P30-HD18258). This work was supported by the National Institutes of Health grant NIH 1R01HD26490-01A1 (S.A. Camper).

\section{References}

Beamer, W.G., Maltais, L.J., DeBaets, M.H., Eicher, E.M. (1987). Inherited congenital goiter in mice. Endocrinology 120, 838-840.

Bennett, D. (1961). Miniature, a new gene for small size in the mouse. J. Hered. 52, 95-98.

Brannan, C.I., Gilbert, D.J., Ceci, J.D., Matsuda, Y., Chapman, V.M., Mercer, J.A., Eisen, H., Johnston, L.A., Copeland, N.G., Jenkins, N.A. (1992). An interspecific linkage map of mouse chromosome 15 positioned with respect to the centromere. Genomics $13,1075-1081$.

Dietrich, W., Katz, H., Lincoln, S.E., Shin, H.-S., Friedman, J., Dracopoli, N., Lander, E.S. (1992). A genetic map of the mouse suitable for typing intraspecific crosses. Genetics 131, 396-423.

Domalik, L.J., Chaplin, D.D., Kirkman, M.S., Wu, R.C., Liu, W., Howard, T.A., Seldin, M.F., Parker, K.L. (1991). Different isozymes of mouse $11 \beta$-hydroxylase produce mineralocorticoids and glucocorticoids. Mol. Endocrinol. 5, 1853-1861.

Drolet, D.W., Scully, K.M., Simmons, D.M., Wegner, M., Chu, K., Swanson, L.W., Rosenfeld, M.G. (1991). TEF, a transcription factor expressed specifically in the anterior pituitary during embryogenesis, defines a new class of leucine zipper proteins. Genes Dev 5, 1739-1753.

Eicher, E.M., Lee, B.K. (1991). Growth hormone receptor (Ghr) and hemoglobin $\alpha$-chain pseudogene 3 (Hba-ps3) map proximal to the myelocytomatosis oncogene $(\mathrm{Myc})$ on mouse Chromosome 15. Mammalian Genome 1, 57-58.

Eidne, K., Taylor, P., Connor, M., Duthie, S. (1993). Isolation, characterization and chromosomal localization of the human thyrotropin releasing hormone receptor. 75th Annual Meeting of the Endocrine Society, p. 437. 
Feinberg, A.P., Vogelstein, B. (1982). A technique for radiolabeling DNA restriction endonuclease fragments to high specific activity. Anal. Biochem. 132, 6-13.

Lossie, A.C., Buckwalter, M.S., Camper, S.A. (1993). Lysyl oxidase (Lox) maps between $G r l-1$ and $A d r b-2$ on mouse Chromosome 18. Mammalian Genome 4, 177-178.

Lyon, M.F., Searle, A.G. (1989). Genetic Variants and Strains of the Laboratory Mouse, 2nd ed. (New York: Oxford University Press).

Mock, B., Neumann, P.E., Eppig, J.T., Huppi, K. (1991). Mouse Chromosome 15. Mammalian Genome 1, (Suppl.), S241-S268.

Reeves, R.H., Crowley, M.R., O'Hara, B.F., Gearhart, J.D. (1990). Sex, strain and species differences affect recombination across an evolutionarily conserved segment of mouse chromosome 16 . Genomics 8, 141-148.

Straub, R., Frech, G., Joho, R., Gershengorn, M. (1990). Expression cloning of a cDNA encoding the mouse pituitary thyrotropinreleasing hormone receptor. Proc. Natl. Acad. Sci. USA 87, 9514-9518.

Taylor, B.A., Rowe, L. (1987). The congenital goiter mutation is linked to the thyroglobulin gene in the mouse. Proc. Natl. Acad. Sci. USA 84, 1986-1990.

Wallace, M.E., Mallyon, S.A. (1972). Unusual recombination values and the mapping of the lethal miniature in the house mouse. Genet. Res. 20, 257-262. 